\title{
The structure of the mud volcano Novosibirsk based on the results of geological and geophysical studies
}

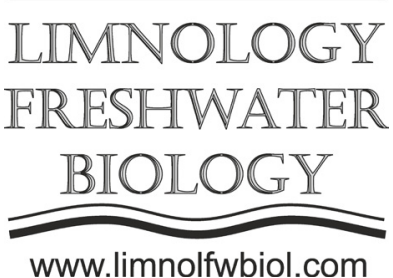

\author{
Khabuev A.V. ${ }^{1 *}$, Solovyeva M.A. ${ }^{2}$, Gubin N.A. ${ }^{3}$, Chensky A.G. ${ }^{3}$, Akhmanov G.G. ${ }^{2}$, \\ Khlystov O.M. ${ }^{1}$
}

\author{
${ }^{1}$ Limnological Institute, Siberian Branch of the Russian Academy of Sciences, Ulan-Batorskaya Str., 3 Irkutsk, Russia \\ ${ }^{2}$ Lomonosov Moscow State University, Leninskie Gory, 1 Moscow, Russia \\ ${ }^{3}$ Irkutsk National Research Technical University, Lermontov Str., 83 Irkutsk, Russia
}

\begin{abstract}
Lake Baikal is the only fresh-water reservoir where gas hydrates were found. More than half of the hydrate-bearing structures are associated with mud volcanism, which makes Baikal mud volcanoes an important object of research and comparison with marine mud volcanoes. Multiple geological and geophysical studies have allowed us to identify elements and characteristics of marine mud volcanism near the mud volcano Novosibirsk.
\end{abstract}

Keywords: Lake Baikal, gas hydrates, mud volcanism

The study of the Baikal mud volcanoes is closely related to the study of near-surface gas hydrates that were first raised in 2000. Since that time, more than 50 hydrate-bearing structures have been discovered, 26 of which contained mud volcanic breccia (Khlystov, 2018).

The mud volcano Novosibirsk was discovered in 2002 within the framework of the Intas project using a side-scan sonar (SSS) at a depth of $1400 \mathrm{~m}$ at the edge of the large ledge, the escarpment of the fault in the central basin of Lake Baikal, which was later called Gidratny (Hydrate) (Fig. 1A) (Khlystov et al., 2018; Solovyeva et al., 2020). The SSS mosaics indicated it as an anomaly in the backscattered signal with a diameter of $700 \mathrm{~m}$ (Fig. 1C).

In the towed deep-sea submersible, in addition to SSS, there was a profilograph that allowed us to obtain the sedimentary sections of up to $40 \mathrm{~m}$ in depth. The BL15_006SO profile passing through the mud volcano clearly indicates the differences in the wave pattern in the bottom sediments of the upper and lower flanks of the Gidratny fault ledge. The sediments of the upper flank are layered, whereas the lower flank is covered with denser and acoustically hard sediments. The mud volcano itself has the elevation with several peaks, under which there is an acoustically transparent zone (Fig. 1C).

Seismoacoustic investigations near the mud volcano were carried out repeatedly in different years. The GAHY077 seismic profile (2002) also clearly indicates a small elevation in the bottom topography and a vertical acoustically transparent channel below. On both sides of the structure, at a depth of approximately $370 \mathrm{~m}$ below the bottom level, there is a line of the base of the gas hydrate stability zone (BGHSZ) that corresponds to the lower boundary of the gas hydrate stability zone (Fig, 1D).

During the studies using the ELAC SeaBeam 1050 and Konengsberg EM710S multi-beam echosounders in 2009 and 2019, respectively, we clarified the relief morphology of this structure. Bathymetric data allowed us to obtain a three-dimensional elevation model with a $10 \mathrm{~m}$ grid cell size, which significantly increased the image detail compared to the bathymetric map of the Intas project (De Batist et al., 2002). The elevation of the mud volcano Novosibirsk has a round form in plan, which is slightly elongated from northwest to southeast. The structure of the mud volcano has a conical shape of $15 \mathrm{~m}$ in height, in the centre of which there is a cavity (crater) of $10 \mathrm{~m}$ in depth (Fig. 1B).

Numerous geological studies using the method of the bottom sampling with a gravity drop corer indicated the presence of the near-bottom gas hydrates as well as mud volcanic breccia in the bottom sediments within the studied structure. Gas hydrates were sampled at the stations from the lowered part of the crater. They were overlapped with bottom sediments having a thickness of at least $70 \mathrm{~cm}$ and had lenses and thin layers. Mud volcanic breccia also occurred in the central part of the structure, within the crater, but it was spread over a wider area (Fig. 1B). In two cores, breccia was found directly on the bottom surface, and in three more cores, it was overlapped with low-thickness sediments (3-4 $\mathrm{cm})$. This indicates a possible recent process of fluid discharge. 


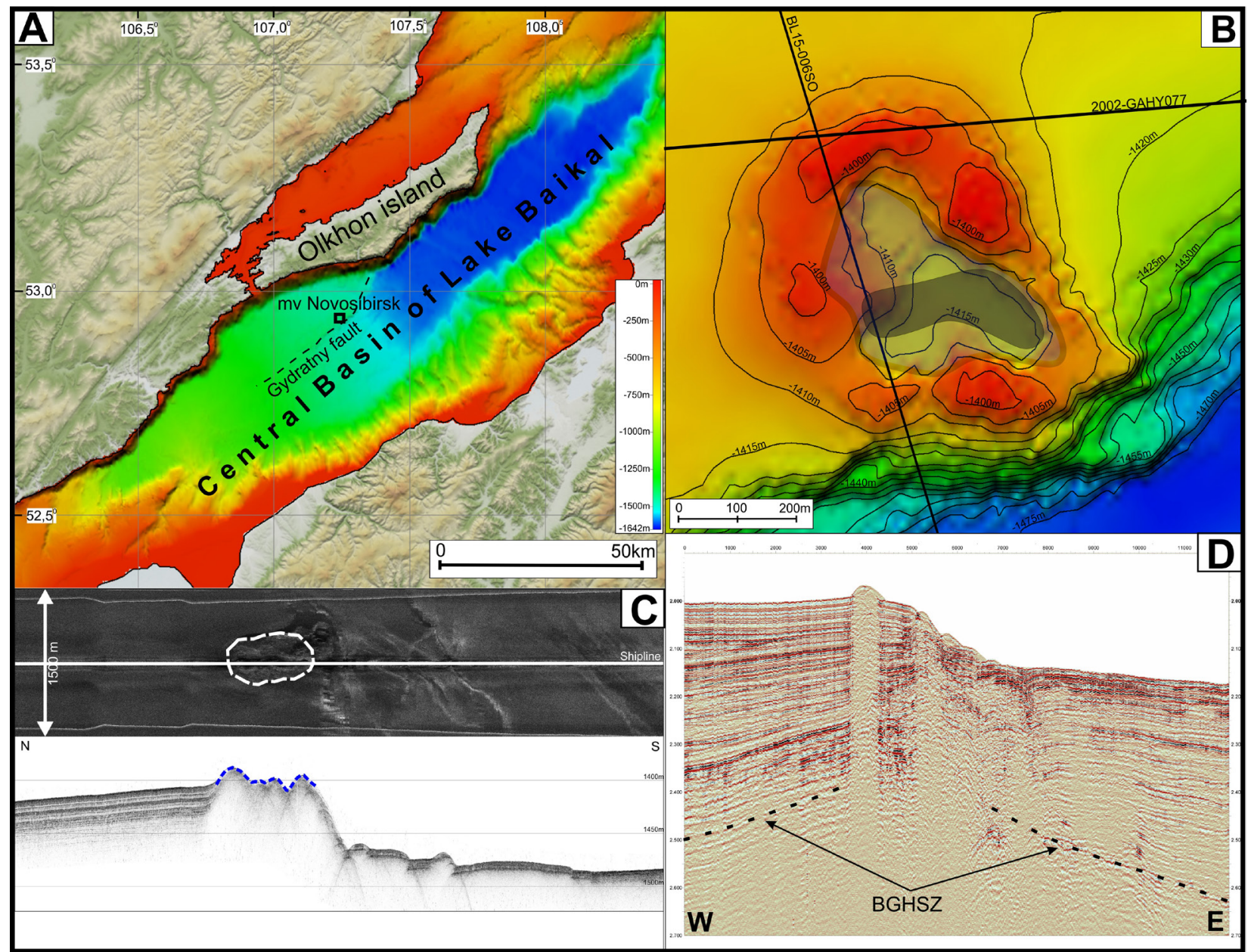

Fig.1. A - Geographic location of the mud volcano Novosibirsk confined to the Gidratny fault. B - bathymetric map of the mud volcano Novosibirsk. The light marked zone is the distribution of mud volcanic breccia, darker zone - the distribution of near-surface gas hydrates. C - the data on the BL15_006SO profile of side-scan sonar (at the top, white dotted line marks the mud volcano) and profilograph (at the bottom, blue dotted line marks the mud volcano). D - the GAHY077 seismic profile through the mud volcano Novosibirsk. The horizontal scale is shown in metres, and the vertical scale - the double travel time of the wave (s).

Therefore, based on geological and geophysical data, we detected elements of marine mud volcanism near the mud volcano Novosibirsk: i) a vent in the body of the volcanic structure (a small elevation with a lowering in the central part) visible in the sonogram as a site with abnormally high backscatter values; ii) the presence of the acoustically transparent vertical channel below; iii) the presence of near-surface gas hydrates and mud volcanic breccia in bottom sediments.

This study was carried out within the framework of the State Task No. 0345-2019-007.

\section{References:}

De Batist M., Canals M., Sherstyankin P. et al. \& the INTAS Project 99-1669 Team. 2002. A new bathymetric map of Lake Baikal. [URL: http://www. lin.irk.ru/intas/index.htm Access date 13.04.2020]

Khlystov O.M. 2018. Gas hydrate bearing capacity and tectonics of Central Baikal. In: VII International Conference on Marine Research and Education, pp. 4344.
Khlystov O.M., Khabuev A.V., Minami H. et al. 2018. Gas hydrates in Lake Baikal. Limnology and Freshwater Biology 1: 66-70. DOI: 10.31951/26583518-2018-A-1-66

Solovyeva M.A., Akhmanov G.G., Mazzini A. et al. 2020. The Gydratny Fault zone of Lake Baikal. Limnology and Freshwater Biology 1: 368-372. DOI: 10.31951/2658-3518-2020-A-1-368 